DOI: 10.18778/2084-140X.08.23

\title{
LeONORA Neville, Heroes and Romans in Twelfth-Century Byzantium. The Material for History of Nikephoros Bryennios, Cambridge University Press, Cambridge 2016, pp. XIV, 243 (paperback).
}

$\mathrm{T}$ he publications by Leonora Alice Neville $(* 1970)$ of the University of WisconsinMadison mostly deal with the Byzantine Empire under the Komnenos dynasty ${ }^{1}$. The period in question saw the rise of a number of crucial historical works that enabled later generations to understand not only the political situation, but also the cultural background against which the writers created their oeuvres. Neville bases her analysis of the work by Nikephoros Bryennios (1062-1137) on Paul Gautier's 1975 critical edition ${ }^{2}$. Neville's study on Bryennios's writings consists of three main parts, further divided into 16 chapters. The entire work is preceded by two condensed genealogical charts of the Komnenos and Doukas dynasties as well as an Introduction (p. I-IX), in which the author clarifies the origin and the turbulent history of the Bryennios family. In the first part of the book, entitled Contexts (p. 13-59, spanning four chapters), Neville provides an outline of the Komnenoi's politics, while also sketching out the practical aspects of historical writings in $12^{\text {th }}$-century Byzantium. Important fragments of this part are devoted to the sources utilized by Bryennios in his Material for History. Neville is of the opinion that Bryennios was a thoroughly educated man (p. 39), as is apparent from his being well-versed in the Bible as well as his imitating ancient authors, such as Homer, Xenophon, Sophocles, Euripides, Polybius, or Plutarch. Furthermore, according to Neville (as well as other scholars), Bryennios's erudition was influenced by a number of authors less distant from him in space and time, such as

\footnotetext{
${ }^{1}$ L.A. Neville, Authority in Byzantine Provincial Society, 950-1100, Cambridge 2004; L.A. Neville, Anna Komnene. The Life and Work of a Medieval Historian, New York 2016 [= OSHC].

${ }^{2}$ Nicéphore Bryennios, Histoire, ed. et trans. P. Gautier, Bruxelles 1975 [= CFHB.SBr, 9]. A Polish translation is available in: Nikefor Bryennios, Materiały historyczne, ed. et trans. O. JuREwICz, Wrocław 2006 (based on ed. of 1974).
}

Michael Psellos or John Skylitzes. Finally, Bryennios also had access to the imperial archives, which no doubt enhanced the value of his narrative. In the second part of the book, entitled Readings in the Material for History (p. 63-170, chapters 5-13), we find a painstakingly detailed analysis of the main object of the study, i.e. the Material for History itself. Bryennios's work covers the years 1070-1079, far from an easy time for the Empire in terms of political and military matters. The chronicler himself views that time as the Empire's all-time low, substantiating this claim with a wealth of examples, all of them most painful for Byzantium: the Seljuk invasion and the defeat in the Battle of Manzikert, the death of emperor Romanos, civil war, problems with the Slavs in Thrace, and issues involving mercenaries. According to Neville, Bryennios realized that the civil war and the dangers coming from the "uncontrollable" (p. 74) mercenaries had led to the Empire abruptly losing much of its capacities in the 1070s. As regards Alexios I Komnenos, Bryennios thought - and tried to demonstrate - that he possessed imperial strength. In a sense, the chronicler thought that in view of the Empire's previous decline, Alexios I and the Komnenoi were the right people to lead the country. Neville emphasizes that it was in the interest of Bryennios himself - as well as the political fraction he belonged to - that Alexios I be emperor. In chapter 7 of this part, where the author ponders the question of who was viewed as an enemy of the Byzantines (Romans), she discusses the issue of how Bryennios approaches the Romans and the Empire; she comes to the conclusion that he tends to focus on the people rather than the state. Thus, he calls other nations (such as Turks or Franks) "barbarians", invoking the relevant ethnonyms. A descendant of military commanders, the chronicler pays attention to issues of Military virtue, to which topic Neville devotes chapter 8 of her work. She analyzes Bryennios's judgments on these matters 
in great detail; her investigations are presented in several interesting charts (p. 90 and 93-94), as well as a conclusions section. In chapter 9, the scholar examines Bryennios's views on Roman family politics, claiming that the historian put particular emphasis on cooperation among family members and relying on it for achieving political gains. In chapter 10 , Neville convincingly argues that Bryennios's narrative is not firmly couched in any particular theological framework; in general, religion is seldom in the foreground, although an inseparable part of Byzantine culture. Chapter 11 is entitled Roman heroes; needless to say, the figure of Nikephoros Bryennios the Elder, the historian's grandfather, is one of the protagonists in this narrative. Neville studies Bryennios's battle descriptions quite meticulously, registering the virtues ascribed to particular figures; her inquiry confirms that the characters depicted by the chronicler correspond to the classical image of a Byzantine warrior. Chapter 12 (A Roman mother) is a survey of imperial mothers, widows, and daughters who lived under the "stigma" of politics. Neville reviews Bryennios's judgments and juxtaposes them with the opinions of other Byzantine authors. In chapter 13 ( $A$ bold young man), she discusses the descriptions of Alexios I Komnenos, portrayed in a number of divergent ways in each of Bryennios's four books. These interpretations are most interesting: although Alexios I is generally viewed as a hero by Bryennios, the chronicler did not fail to point out his negative traits as well. In the third part of the work - The Material for History in Twelfth-Century politics and culture (p. 171-203) - the author points out that Bryennios's work had certain purely practical aspects, being actively used in contemporary politics. Thus, Bryennios's critique of Alexios I was political in nature (p. 173). In chapter 15 (Nikephoros and Anna, p. 182-193), Neville directs attention to Bryennios's wife Anna, the daughter of Alexios I. Finally, in chapter 16 - entitled Roman ideals and twelfth-century Constantinopolitan culture (p. 194-203) - she investigates the role of such ideals in Constantinople in the early $12^{\text {th }}$ century. Neville compares the world of the figures that Bryennios knew in his time with the characters depicted by classical writers of antiquity.
Leonora Neville's thought-provoking study of Bryennios's testimony is certainly an important contribution to the scholarly debate on the matter. To be sure, the author only rarely alludes to earlier historiographical discussions, but this does not seem to have been her objective; on the other hand, she makes ample use of primarily sources, which she quotes in the original as well as in English translation. Neville is confident in the importance of gender studies, as seen in chapter 12 and 15 . The publication is closed by two Appendices, a selective bibliography and an index. Neville claims that Bryennios's effort has not been fully appreciated in the historiography, not least because of the towering status of the work by his wife Anna, i.e. the Alexiad. The scholar also points out that Bryennios extols the figure of his grandfather - a usurper, but also a man of honor. Accordingly, the narrative revolves around the notion of honor, alluding to the traditional understanding of this concept in Roman times. Well-written and testifying to the author's erudition and imaginativeness, Neville's publication is a must-read for all Byzantinists, particularly those studying the age of the Komnenoi. It provides important insight into the Byzantines' understanding of the notion of honor - not only in Bryennios's times.

\section{BibLIOGRAPHY}

\section{Primary Sources}

NicéPhore Bryennios, Histoire, ed. et trans. P. GAUTIER, Bruxelles 1975 [= Corpus Fontium Historiae Byzantinae. Series Bruxellensis, 9].

Nikefor Bryennios, Materialy historyczne, ed. et trans. O. JuREwicz, Wrocław 2006.

\section{Secondary literature}

Neville L.A., Anna Komnene. The Life and Work of a Medieval Historian, New York 2016 [= Onassis Series in Hellenic Culture].

Neville L.A., Authority in Byzantine Provincial Society, 950-1100, Cambridge 2004.

\section{Zdzisław Pentek (Poznań)*} Translated by Marek Majer

\footnotetext{
* Uniwersytet im. Adama Mickiewicza w Poznaniu, Wydział Historyczny, Instytut Historii
} 